\title{
Rh NPs Immobilized on Phosphonium- based Supported lonic Liquid Phases (Rh@SILPs) as Hydrogenation Catalysts
}

\author{
Johannes Zennereabs, Gilles Moos ${ }^{\text {abs }}$, Kylie L. Luska ${ }^{\mathrm{b}}$, Alexis Bordet ${ }^{\mathrm{a}}$, and Walter Leitner ${ }^{\mathrm{ab} *}$
}

\begin{abstract}
A series of phosphonium-based supported ionic liquid phases (SILPs) was prepared for the immobilization of Rh nanoparticles (Rh@SILP). The influence of systematic variations in the structure of the ionic liquid-type molecular modifiers (anion, $P$-alkyl chain length) on the formation and catalytic properties of Rh nanoparticles (NPs) was investigated. Both the nature of the anion and the length of the $P$-alkyl chain were found to have a strong impact on the morphology of the NPs, ranging from small $(1.2-1.7 \mathrm{~nm})$ and well-dispersed NPs to the formation of large NPs (9.9-16.5 nm) and/or aggregates. The catalytic properties of the resulting Rh@SILP materials were explored using the hydrogenation of benzylideneacetone and biomass-derived furfuralacetone as model reactions. The changes in ring and $\mathrm{C}=\mathrm{O}$ hydrogenation activity as a function of the SILP structure and the Rh NPs size allowed for the selective synthesis of products with distinct molecular functionalities.
\end{abstract}

Keywords: Biomass · Hydrogenation · Phosphonium-based ionic liquids · Rhodium nanoparticles · Supported ionic liquid phases

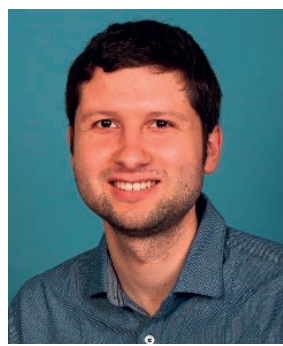

Johannes Zenner studied chemistry at RWTH Aachen university, where he obtained his BSc in Chemistry in 2017. During his Master's studies, he performed a research internship at Queen's University in Kingston, Canada funded by the Mitacs Globalink program. In 2019 he joined the department of Molecular Catalysis led by Prof. Walter Leitner at the Max Planck Institute for Chemical Energy Conversion for his master's thesis, where he subsequently started his $\mathrm{PhD}$ in the Multifunctional Catalytic Systems team (2020-present).

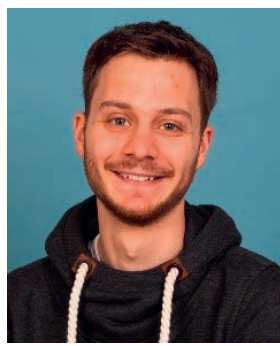

Gilles Moos studied chemistry at RWTH Aachen University and obtained his BSc in 2015 for his work on sugar isomerization. In 2017, he joined the group of Prof. Walter Leitner for the preparation of his Master's thesis at the RWTH Aachen University. Currently he is working as a PhD student at the Max Planck Institute for Chemical Energy Conversion in the team of Multifunctional Catalytic Systems, as part of the department of Molecular Catalysis.

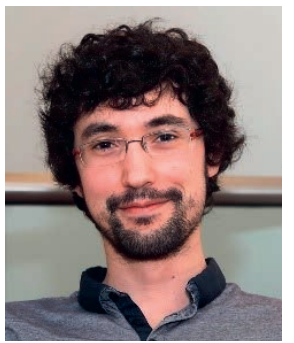

Alexis Bordet is a Group Leader at the Max Planck Institute for Chemical Energy Conversion. He leads the team of Multifunctional Catalytic Systems in the department of Molecular Catalysis directed by Walter Leitner. He performed his $\mathrm{PhD}$ under the guidance of Prof. Bruno Chaudret and obtained his doctoral degree from the University of Toulouse in December 2016.
He conducted postdoctoral research for one year in the group of Prof. Walter Leitner at the RWTH Aachen (2017-2018) before starting as a Group Leader at the MPI-CEC in February 2018.

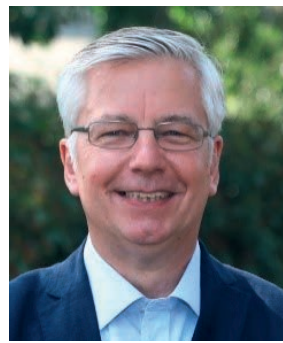

Walter Leitner is Director at the Max Planck Institute for Chemical Energy Conversion in Mülheim an der Ruhr and holds the Chair of Technische Chemie und Petrolchemie at RWTH Aachen University. $\mathrm{He}$ is also Scientific Director of CAT, the joint Catalytic Center of RWTH Aachen and the company Covestro. His research focusses on a molecular approach to catalysis motivated by the principles of green chemistry. From 2004-2016, he served first as Scientific Editor and later as Chairman of the Editorial Board of the Journal Green Chemistry, published by the Royal Society of Chemistry (UK) and since 2018 he is a member of the Editorial Board of Angewandte Chemie.

\section{Introduction}

With depleting fossil resources, the utilization of renewable resources for the production of fuels and chemicals represents currently one of the biggest challenges for the chemical industry. ${ }^{[1]}$ Extensive efforts are in particular dedicated to the conversion of biomass-derived feedstock into value-added compounds including fuels, bulk and fine chemicals as well as building blocks for the production of pharmaceuticals. ${ }^{[2]}$ Selective catalytic hydrogenation plays a key role in this upgrading process, and the development of innovative catalytic systems combining excellent activity, selectivity and stability is required. ${ }^{[3]}$ Several strategies can be adopted to tune selectivity in hydrogenation reactions, among which the use of metal nanoparticles immobilized on molecularly modifier surfaces (NPs@MMS) as catalysts is particularly promising. ${ }^{[4]}$ The careful choice of NPs@MMS components (support

${ }^{*}$ Correspondence: Prof. W. Leitnerab, E-mail: walter.leitner@cec.mpg.de; Dr. A. Bordeta ${ }^{\text {a }}$ E-Mail: alexis.bordet@cec.mpg.de 
material, molecular modifier, metal nanoparticles) indeed allows controlling precisely the activation of the substrates as well as of hydrogen (homolytic versus heterolytic activation). ${ }^{[4]]}$ As a result, various functionalities (alkenes, arenes, ketones, etc.) can be selectively hydrogenated in complex molecules, including biomassderived substrates. ${ }^{[4 \mathrm{f}, 5]}$ Among MMS materials, supported ionic liquid phases (SILPs) are of particular interest as they combine the beneficial properties of bulk ionic liquids (ILs) with those of solid supports, providing advantages such as tunable wettability, improved mass transfer, enhanced NPs stability, easy recycling and implementation in continuous flow processes, etc. $^{[4 \mathrm{c}, \mathrm{d}, 6]}$ NPs@SILP catalytic systems are highly tunable, and have been successfully applied to challenging hydrogenation ${ }^{[5 \mathrm{a}, \mathrm{c}-\mathrm{g}]}$ and hydrodeoxygenation $^{[7]}$ reactions. However, while understanding the relation between SILPs' molecular structure and the resulting NPs size and catalytic properties is essential to achieve a knowledgebased catalyst design, this remains widely elusive until now. ${ }^{[4 f, 8]}$ In this context, our group recently investigated the influence of the molecular structure of imidazolium-based SILPs on the synthesis and catalytic properties of Rh NPs in Rh@SILP materials. ${ }^{[6 d]}$ The structure of the chemisorbed ILs ( $N$-alkyl chain length, spacer length, anion) was found to have a very significant impact on the size (0.7-2.0 $\mathrm{nm}$ range) and hydrogenation performances of $\mathrm{Rh}$ NPs. In addition, it was demonstrated that Rh@SILP catalysts possess a much better stability than a reference catalyst composed of $\mathrm{Rh}$ nanoparticles of similar size immobilized on unmodified $\mathrm{SiO}_{2}$.

Compared to imidazolium-based ILs, phosphonium-based ILs are typically less expensive and possess higher thermal, chemical and electrochemical stability. ${ }^{[9]}$ Effects of the molecular structure of phosphonium-based bulk IL on NP size and catalytic performance have been investigated in Suzuki crosscoupling ${ }^{[10]}$ and hydrogenation ${ }^{[11]}$ reactions, however no consistent trends could be observed in these studies. Luska et al. prepared Ru NPs in bulk phosphonium-based ILs with the general structure $\left[\mathrm{PBu}_{3} \mathrm{R}\right] \mathrm{X}(\mathrm{R}=P$-alkyl chain length; $\mathrm{X}=$ anion $)$ for the hydrogenation of cyclohexene. Ru NPs immobilized in ILs with increasing $\mathrm{R}$ showed an enhanced stability. The nature of $\mathrm{X}$ also had an influence on the Ru NP size, with small NPs observed in the presence of $\mathrm{NTf}_{2}$ (bis(trifluoromethane)sulfonimide) and OTf (trifluoromethanesulfonate), while for $\mathrm{PF}_{6}$ and $\mathrm{Cl}$ the NPs were larger with a broad size distribution and tended to aggregate more during catalysis. ${ }^{[12]}$
Herein, we report the preparation of various phosphoniumbased SILPs and their use as supports for the immobilization of Rh NPs (Fig. 1a). The molecular structure of the IL-type modifiers was systematically varied, changing in particular the length of the $P$-alkyl chains and the nature of the anion to evaluate the influence of these components on the morphology and catalytic properties of the resulting Rh NPs. SILP and Rh@SILP materials were characterized using various techniques including $\mathrm{N}_{2}$ adsorption, IR, TEM and ICP (Fig. 1b). The catalytic performances of the Rh@ SILP materials were evaluated in the hydrogenation of furfuralacetone and benzylideneacetone (Fig. 1c). Both of these substrates contain various unsaturated moieties that allow probing finely the hydrogenation capabilities of the prepared catalytic systems. In addition, furfuralacetone can be accessed from biomass-derived furfural, ${ }^{[1 a, 13]}$ and its hydrogenation products are considered as interesting intermediates in the production of fuels and fuel additives. ${ }^{[14]}$

\section{Results and Discussion}

\subsection{Synthesis and Characterization Rh@SILP Catalysts}

A series of phosphonium-based ILs was synthesized by adapting a previously reported procedure. ${ }^{[15]}$ These ILs will be denoted as $\mathrm{R}_{3}-\mathrm{P}-\mathrm{X}$, where $\mathrm{R}$ corresponds to the $P$-alkyl chains $(\mathrm{R}=\mathrm{Me}$, $\left.\mathrm{Bu},{ }^{t} \mathrm{Bu}, \mathrm{Oct}\right)$ and $\mathrm{X}$ to the anion $\left(\mathrm{X}=\mathrm{I}, \mathrm{OTf}, \mathrm{PF}_{6}, \mathrm{NTf}_{2}\right)$. The synthesis involved the quaternization of different trialkyl phosphines with 3-iodopropyltriethoxysilane. The ILs were further tuned by performing anion exchanges to replace the iodide by the OTf, $\mathrm{PF}_{6}$ and $\mathrm{NTf}_{2}$ anions. The resulting ILs are liquid at room temperature except for $\mathrm{Me}_{3}-\mathrm{P}-\mathrm{I}$ and ${ }^{t} \mathrm{Bu}_{3}$-P-I which appear as solids. This is presumably due to their sterically less demanding $P$-alkyl chains, causing the ionic forces between the molecules to dominate. Similar trends could be observed for imidazolium-based ILs, where the melting point generally decreased with increasing $N$-alkyl chain length.[16]

Following an established procedure, the ILs were grafted onto dehydroxylated $\left(500{ }^{\circ} \mathrm{C}\right.$ overnight under high vacuum) silica via silanization (see Supplementary Information for complete experimental procedures and characterization data). ${ }^{[7 a]}$ An overview of the synthesized SILPs is given in Fig. 2.

The IL loadings on the SILPs were determined by isolating the unreacted IL after the silanization reaction (Table 1). On SILP( $\left.\mathrm{R}_{3}-\mathrm{P}-\mathrm{I}\right)$ materials, an increase of the $P$-alkyl chain length
Fig. 1. Illustration of the approach followed in this study: a) organometallic synthesis of Rh@SILP, b) characterization of the supports and catalysts and c) catalytic hydrogenation of furfuralacetone and benzylideneacetone. a)
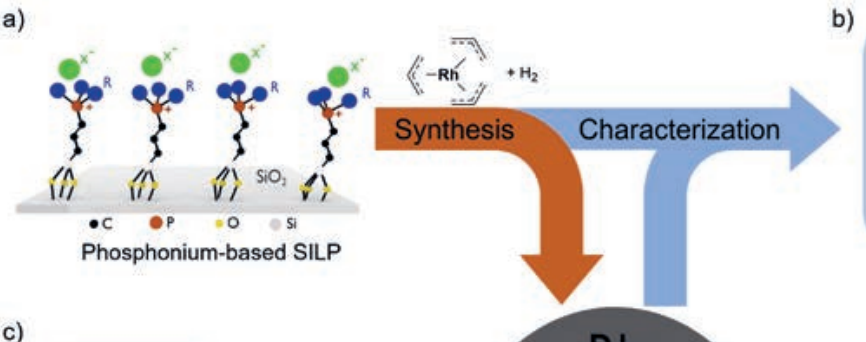

)

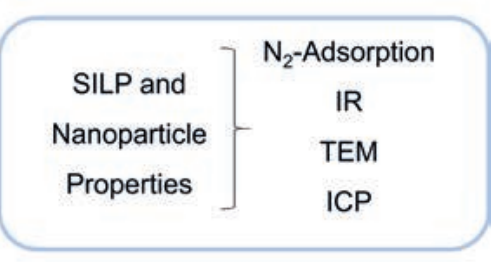

c)

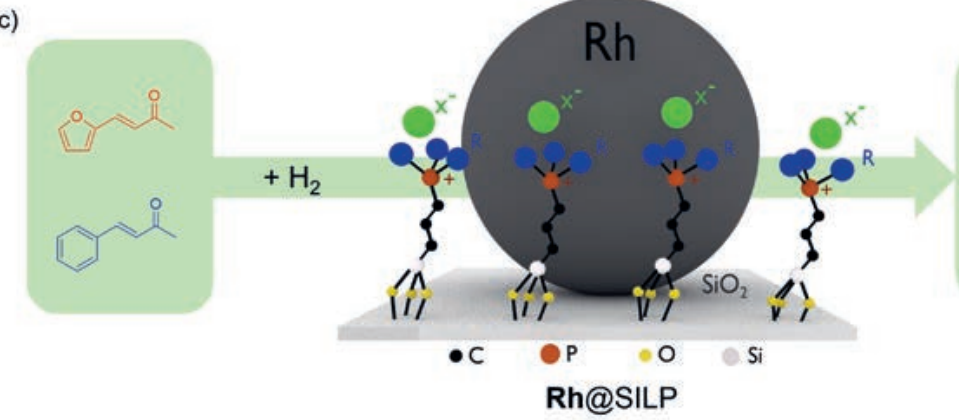




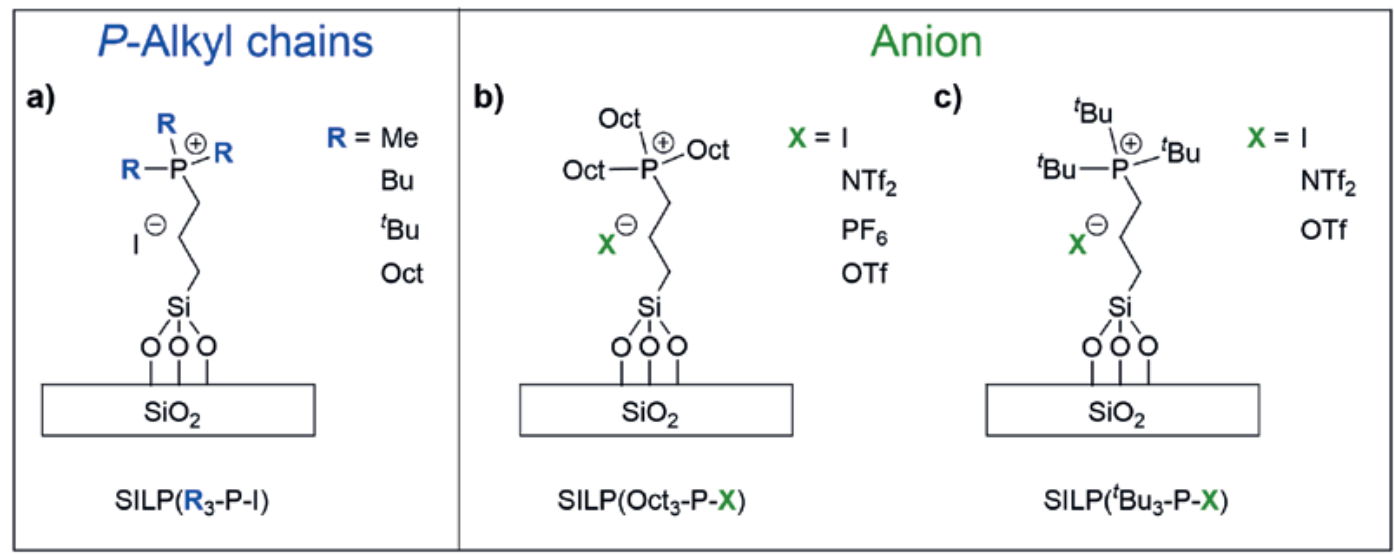

Fig. 2. Phosphonium-based supported ionic liquid phases (SILPs) prepared through the variation of a) the $P$-alkyl chains for $\operatorname{SILP}\left(\mathrm{R}_{3}-\right.$ $P-I)$, and of the anion for $b)$ SILP(Oct $-P-X)$ and c) SILP(tBu $\mathrm{P}-\mathrm{X}) . \mathrm{NTf}_{2}=$ bis(fluoromethane) sulfonimide and OTf = trifluoromethanesulfonate.

was associated to a decrease in IL loading (from $\mathrm{R}=\mathrm{Me}$ and ${ }^{t} \mathrm{Bu}$ to $\mathrm{Bu}$ and $\mathrm{Oct}$ ). A similar observation was made when varying the $N$-alkyl chain length in imidazolium-based SILPs. ${ }^{[6 \mathrm{~d}]}$ No significant influence of the anion on the IL loading could be identified. Characterization of the supports by $\mathrm{N}_{2}$ adsorption showed the expected decrease in surface area, pore size and volume of the SILPs compared to unmodified silica. However, no significant trends could be derived from the variation of the $P$-alkyl chain and anion. Several SILPs were further characterized using diffuse reflectance infrared Fourier transform spectroscopy (DRIFTS, Fig. S1 in the Supplementary Information). The sharp band at 3700 $\mathrm{cm}^{-1}$ corresponding to isolated surface $\mathrm{Si}-\mathrm{OH}$ species of dehydroxylated silica is significantly weaker after the grafting of the ILs. Additionally, the C-H stretch bands between $3000 \mathrm{~cm}^{-1}$ and $2800 \mathrm{~cm}^{-1}$ characteristic of the alkyl-chains of the IL are visible for the SILPs, indicating the successful immobilization of the IL.

Rh NPs were synthesized following an organometallic approach involving the wet impregnation of the supports $(0.5 \mathrm{~g})$ with a solution of $\left[\mathrm{Rh}(\text { allyl })_{3}\right](11.3 \mathrm{mg}, 0.05 \mathrm{mmol})$ in dichloromethane $(5 \mathrm{~mL})$ to achieve a targeted $\mathrm{Rh}$ loading of $0.1 \mathrm{mmol} / \mathrm{g}_{\text {support }}$ or approximately $1.0 \mathrm{wt} \% .{ }^{[6 \mathrm{~d}]}$ The solvent was removed in vacuo and the organometallic precursor was reduced under $\mathrm{H}_{2}$ (100 bar, $\left.100{ }^{\circ} \mathrm{C}, 2 \mathrm{~h}\right)$. A black powder was obtained, indicating the formation of Rh NPs. The Rh loadings were determined by inductively coupled plasma-optical emission spectrometry (ICP-OES) and found to be in agreement with the theoretical value (Table 2). Rh@SiO, and Rh@SILP materials were characterized by transmission electron microscopy (TEM) to investigate the size and dispersion of Rh NPs on the various supports (Table 2, Fig. 3 and Figs. S2-S11).

$\mathrm{Rh}$ NPs prepared on unmodified $\mathrm{SiO}_{2}$ were found to be small $(1.2 \mathrm{~nm})$ and well dispersed, in agreement with previous reports. [6d] In contrast, the presence and nature of the phosphonium-based ILs had a significant influence on the NPs formation, ranging from large aggregates $(>100 \mathrm{~nm}$ ) to small and homogeneously distributed NPs $(1.2-1.7 \mathrm{~nm})$. Starting with the iodide-containing SILPs, mostly large agglomerates (10 to $>100 \mathrm{~nm})$ were observed for Rh@SILP( $\left.\mathrm{Me}_{3}-\mathrm{P}-\mathrm{I}\right)$ and Rh@SILP(Bu$\left.-\mathrm{P}-\mathrm{I}\right)$, while smaller NPs $(9.9 \pm 4.7 \mathrm{~nm})$ were formed on Rh@SILP $\left({ }^{t} \mathrm{Bu}_{3}-\mathrm{P}-\mathrm{I}\right)$. Rh@SILP(Oct $-\mathrm{P}-\mathrm{I})$ showed very small and well dispersed NPs $(1.3 \pm 0.3 \mathrm{~nm}$, Fig. 3a). No aggregates were observed on the OTfcontaining SILPs, although the NPs sizes were quite large (16.5 and $14.5 \mathrm{~nm}$ for Rh@SILP $\left({ }^{t} \mathrm{Bu}_{3}\right.$-P-OTf) and Rh@SILP(Oct $-\mathrm{P}-$ OTf), respectively) with a broad size distribution. Two NP size populations could be observed for Rh@SILP(Oct $\left.-\mathrm{P}_{-} \mathrm{PF}_{6}\right)$ with the presence of small NPs $(1.7 \pm 0.7 \mathrm{~nm})$ as well as larger agglomerates $(10-100 \mathrm{~nm})$. For $\mathrm{NTf}_{2}$ as anion, small $(1.2-1.4 \mathrm{~nm})$ and well-dispersed NPs with sizes comparable to $\mathrm{Rh} @ \mathrm{SiO}_{2}$ could be obtained. It could be shown that the structure of phosphoniumbased ILs has a very significant effect on the size of Rh NPs pre-
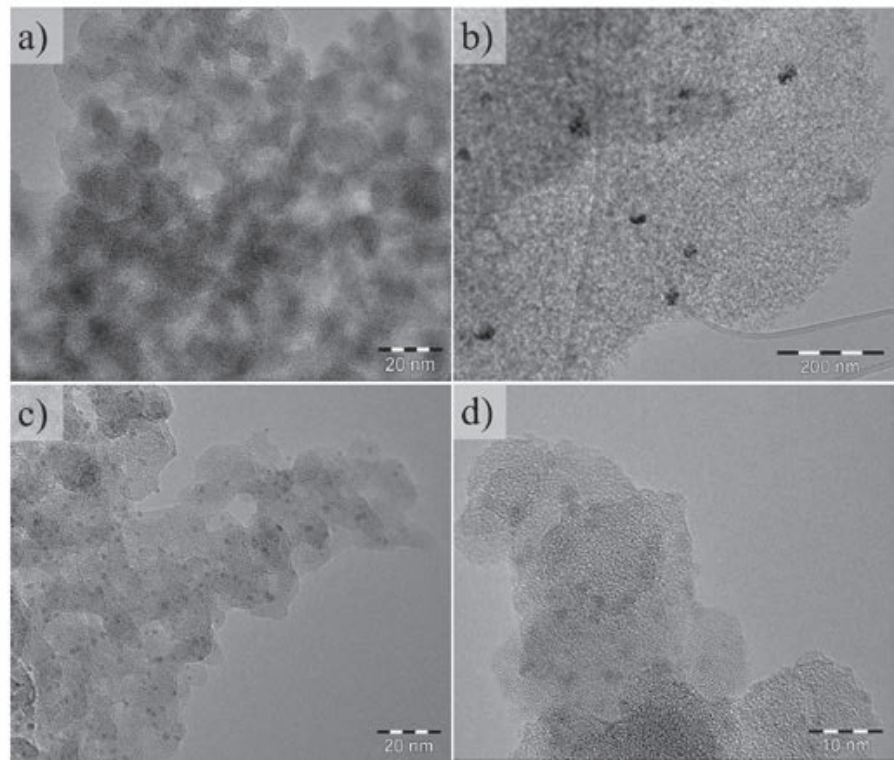

Fig. 3. Transmission electron microscopy characterization of a) Rh@ SILP(Oct $\left.-\mathrm{P}-\mathrm{I}), \mathrm{b}) \mathrm{Rh@SILP}\left({ }^{\mathrm{t}} \mathrm{Bu}_{3}-\mathrm{P}-\mathrm{OTf}\right), \mathrm{c}\right) \mathrm{Rh} @ \mathrm{SILP}\left(\mathrm{Oct}_{3}-\mathrm{P}-\mathrm{NTf}_{2}\right)$ and d) $\mathrm{Rh}$ SILP( $\left.{ }^{t} \mathrm{Bu}_{3}-\mathrm{P}-\mathrm{NTf}_{2}\right)$.

pared on the corresponding SILPs. Both the nature of the anion and the $P$-alkyl chain length influence the NP size, while such strong effects were not observed for imidazolium-based Rh@ SILP materials. [6d]

\subsection{Catalytic Study}

Biomass-derived furfuralacetone (1) was selected as model substrate to probe the hydrogenation performances of Rh@SILP catalysts as it possesses various functionalities (furan ring, $\mathrm{C}=\mathrm{C}$, ketone) offering the possibility to evaluate variations in the catalytic activity and selectivity by analysis of the product spectrum (Fig. 4). In addition, through its selective hydrogenation, relevant chemical products can be accessed which can be employed as intermediates for the production of potential fuels or fuel additives. ${ }^{[1 \mathrm{~g}]}$

In the first step of the hydrogenation network, the $\mathrm{C}=\mathrm{C}$ double bond is hydrogenated, yielding the unsaturated ketone 4-(2-furanyl)-2-butanone (2). The following hydrogenation step either consists of a) the hydrogenation of the furan ring to the saturated ketone 4-(tetrahydro-2-furanyl)-2-butanone (3) or b) the hydrogenation of the ketone, giving the unsaturated alcohol $\alpha$-methyl-2-furanpropanol (4). In the final hydrogenation step, both paths converge to give the saturated alcohol tetrahydro$\alpha$-methyl-2-furanpropanol (5). The catalytic hydrogenation of 
Table 1. IL loadings and $\mathrm{N}_{2}$ adsorption measurements of the supports.

\begin{tabular}{|c|c|c|c|c|}
\hline Support & $\begin{array}{l}\text { IL loading }{ }^{\mathrm{a}} \\
{\left[\mathrm{mmol}^{\left.-\mathrm{g}^{-1}\right]}\right.}\end{array}$ & $\begin{array}{l}\text { Surface area } \\
{\left[\text { BET, } \mathbf{m}^{2} \cdot \mathrm{g}^{-1}\right]}\end{array}$ & $\begin{array}{l}\text { Pore size } \\
{[\mathrm{nm}]}\end{array}$ & $\begin{array}{l}\text { Pore volume } \\
{\left[\mathrm{cm}^{3} \cdot \mathrm{g}^{-1}\right]}\end{array}$ \\
\hline $\mathrm{SiO}_{2}$ & - & 342.3 & 8.8 & 1.07 \\
\hline $\operatorname{SILP}\left(\mathrm{Me}_{3}-\mathrm{P}-\mathrm{I}\right)$ & 0.67 & 251.8 & 8.7 & 0.73 \\
\hline $\operatorname{SILP}\left(\mathrm{Bu}_{3}-\mathrm{P}-\mathrm{I}\right)$ & 0.58 & 258.0 & 8.7 & 0.65 \\
\hline $\operatorname{SILP}\left({ }^{t} \mathrm{Bu}_{3}-\mathrm{P}-\mathrm{I}\right)$ & 0.72 & n.d. & n.d. & n.d. \\
\hline $\operatorname{SILP}\left({ }^{t} \mathrm{Bu}_{3}-\mathrm{P}-\mathrm{NTf}_{2}\right)$ & 0.70 & 259.7 & 8.7 & 0.60 \\
\hline $\operatorname{SILP}\left({ }^{\prime} \mathrm{Bu}_{3}-\mathrm{P}-\mathrm{OTf}\right)$ & 0.72 & n.d. & n.d. & n.d. \\
\hline SILP(Oct 3 -P-I) & 0.47 & 270.8 & 8.6 & 0.69 \\
\hline $\operatorname{SILP}\left(\mathrm{Oct}_{3}-\mathrm{P}-\mathrm{NTf}_{2}\right)$ & 0.51 & 214.2 & 6.4 & 0.61 \\
\hline SILP(Oct - -P-OTf $)$ & 0.61 & n.d. & n.d. & n.d. \\
\hline $\operatorname{SILP}\left(\mathrm{Oct}_{3}-\mathrm{P}-\mathrm{PF}_{6}\right)$ & 0.49 & n.d. & n.d. & n.d. \\
\hline
\end{tabular}

Table 2. Characterization of the catalysts by transmission electron microscopy (TEM, NP size distribution) and inductively coupled plasma (ICP-OES, Rh loading).

\begin{tabular}{|c|c|c|}
\hline Catalyst & NP size $[\mathrm{nm}]^{\mathrm{a}}$ & 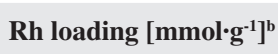 \\
\hline $\mathrm{Rh} @ \mathrm{SiO}_{2}$ & $1.2 \pm 0.2$ & 0.098 \\
\hline $\mathrm{Rh} @ \operatorname{SILP}\left(\mathrm{Me}_{3}-\mathrm{P}-\mathrm{I}\right)$ & $\begin{array}{l}\text { Aggregates } \\
(30-100 \mathrm{~nm})\end{array}$ & 0.094 \\
\hline Rh@SILP(Bu $-\mathrm{P}-\mathrm{I})$ & $\begin{array}{l}\text { Aggregates } \\
(10-100 \mathrm{~nm})\end{array}$ & 0.096 \\
\hline Rh@SILP('Bu $-\mathrm{P}-\mathrm{I})$ & $9.9 \pm 4.7$ & 0.073 \\
\hline Rh@SILP(Oct 3 -P-I) & $1.3 \pm 0.3$ & 0.090 \\
\hline $\mathrm{Rh} @ \operatorname{SILP}\left({ }^{\prime} \mathrm{Bu}_{3}\right.$-P-OTf) & $16.5 \pm 7.8$ & n.d. \\
\hline Rh@SILP(Oct 3 -P-OTf) & $14.5 \pm 7.3$ & 0.079 \\
\hline $\mathrm{Rh} @ \operatorname{SILP}\left(\mathrm{Oct}_{3}-\mathrm{P}-\mathrm{PF}_{6}\right)$ & $\begin{array}{c}1.7 \pm 0.7+\text { Aggregates } \\
(30-100 \mathrm{~nm})\end{array}$ & 0.085 \\
\hline 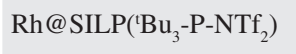 & $1.2 \pm 0.3$ & n.d. \\
\hline $\mathrm{Rh} @ \operatorname{SILP}\left(\mathrm{Oct}_{3}-\mathrm{P}-\mathrm{NTf}_{2}\right)$ & $1.4 \pm 0.5$ & 0.114 \\
\hline
\end{tabular}

${ }^{a} \mathrm{NP}$ size distributions were determined from TEM images by measuring at

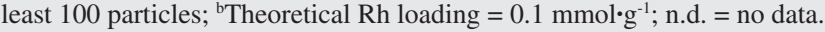

Fig. 4. Hydrogenation network of furfuralacetone (1).

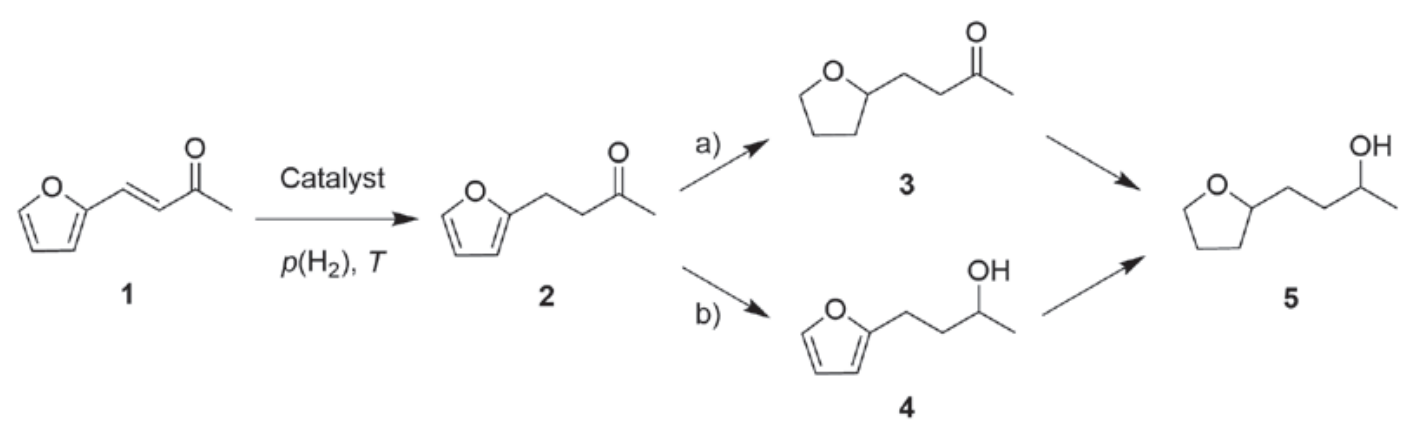

furfuralacetone using noble metal catalysts typically follows pathway a) with the fully hydrogenated product $\mathbf{5}$ being the main product. ${ }^{[5 b, g, 6 d]}$ The use of bifunctional catalytic systems formed by the introduction of an acidic functionality in the IL or SILP ${ }^{[7 a-d]}$ allow further conversion of $\mathbf{5}$, for example by deoxygenation or ring-opening to produce fuels and fuel additives, ${ }^{[17]}$ however, these methods will not be discussed in this study.

Catalytic studies involving the Rh@SILP catalysts were conducted in batch conditions using high-pressure stainless-steel autoclaves $(10 \mathrm{~mL})$. In a typical experiment, the Rh@ SILP catalyst (40.0 $\mathrm{mg}, 0.004 \mathrm{mmol}$ of $\mathrm{Rh}$ ) was added to a solution of furfuralacetone (54.5 mg, $0.40 \mathrm{mmol}, 100$ eq.) in heptane $(0.5 \mathrm{~mL})$. The reaction was performed under $\mathrm{H}_{2}$ (20 bar) with the reactor heated to $100{ }^{\circ} \mathrm{C}$ in an aluminium cone. The influence of the systematic variations in structural parameters of the SILPs on the catalytic properties of Rh NPs was investigated. First, the effect of variations of the $P$-alkyl chain length in Rh@SILP(R $\left.\mathrm{R}_{3}-\mathrm{P}-\mathrm{I}\right)$ catalysts was studied in 4 and $18 \mathrm{~h}$ reactions (Table 3 ). After $4 \mathrm{~h}$ of reaction, the unsaturated ketone $\mathbf{2}$ was the main product for all the catalysts tested. Using Rh@ $\operatorname{SILP}\left(\mathrm{Me}_{3}-\mathrm{P}-\mathrm{I}\right)$, the conversion remained low $(25 \%)$, and 2 was the only product observed. In sharp contrast, Rh@SILP(Bu 3 -P-I $)$ and Rh@SILP(Oct $-\mathrm{P}-\mathrm{I})$ led to full conversion and to mixtures of $\mathbf{2}(96 \%$ and $91 \%$, respectively) and $\mathbf{3}$ (4\% and $9 \%$, respectively). This suggests that an increase in the $P$-alkyl chain length results in an increase in catalytic activity. Surprisingly, Rh@ $\operatorname{SILP}\left({ }^{t} \mathrm{Bu}_{3}-\mathrm{P}-\mathrm{I}\right)$ showed almost no activity. Similar observations were made after $18 \mathrm{~h}$ reactions. Interestingly, the $\mathrm{Rh} @ \mathrm{SILP}\left(\mathrm{Oct}_{3}-\mathrm{P}-\mathrm{I}\right)$ catalyst led to high yields of $\mathbf{3}(87 \%)$, while the other catalysts still gave $\mathbf{2}$ as the major product.

The superior furan ring hydrogenation activity of Rh@SILP(Oct P-I) (87\% of 3 after $18 \mathrm{~h}$ ) compared to the other catalysts may originate from the presence of small and well-dispersed NPs. However, it is worth noticing that none of these catalysts displayed any $\mathrm{C}=\mathrm{O}$ hydrogenation activity, and that their overall catalytic activity appears quite low considering $\mathrm{Rh}$-based catalysts. Their hydrogenation activity is indeed much lower compared to Rh NPs on non-functionalized silica, which converts $67 \%$ of $\mathbf{1}$ to the fully hydrogenated product 5 in $18 \mathrm{~h}$, with $\mathbf{3}(30 \%)$ and $\mathbf{4}(3 \%)$ as co-products. Besides the presence of large aggregates in some Rh@SILP catalysts, this is presumably due to the presence of iodide, which is known to bind strongly at the surface of metal NPs and poison their active sites. ${ }^{[18]}$ From these results, it is clear that the catalytic activity of Rh NPs for the hydrogenation of furfuralacetone is significantly influenced by the structure of the $P$-alkyl chain of phosphonium-based SILPs.

Next, the influence of the nature of the anion $\left(X=I\right.$, OTf, $\mathrm{PF}_{6}$, $\left.\mathrm{NTf}_{2}\right)$ on the performances of Rh@SILP(Oct $\left.-\mathrm{P}-\mathrm{X}\right)$ catalysts for the hydrogenation of furfuralacetone was investigated (Table 4). While Rh@SILP(Oct $-\mathrm{P}-\mathrm{I})$ gave 2 as main product (91\%) after 4 h, Rh@ 
Table 3. Hydrogenation of furfuralacetone using Rh@SILP with different $P$-alkyl chains.

\begin{tabular}{|c|c|c|c|c|c|c|c|}
\hline \multirow[b]{2}{*}{ Time (h) } & \multirow[b]{2}{*}{ Support } & \multirow[b]{2}{*}{ NP size (nm) } & \multirow[b]{2}{*}{ Conversion $(\%)$} & \multicolumn{4}{|c|}{ Product yield $(\%)^{\mathrm{a}}$} \\
\hline & & & & & & & \\
\hline \multirow{4}{*}{4} & $\operatorname{SILP}\left(\mathrm{Me}_{3}-\mathrm{P}-\mathrm{I}\right)$ & aggregates & 25 & 25 & $<1$ & 0 & 0 \\
\hline & $\operatorname{SILP}\left(\mathrm{Bu}_{3}-\mathrm{P}-\mathrm{I}\right)$ & aggregates & $>99$ & 96 & 4 & 0 & 0 \\
\hline & $\operatorname{SILP}\left(\mathrm{Oct}_{3}-\mathrm{P}-\mathrm{I}\right)$ & $1.3 \pm 0.3$ & $>99$ & 91 & 9 & 0 & 0 \\
\hline & $\operatorname{SILP}\left({ }^{\prime} \mathrm{Bu}_{3}-\mathrm{P}-\mathrm{I}\right)$ & $9.9 \pm 4.7$ & 8 & 8 & 0 & 0 & 0 \\
\hline \multirow{4}{*}{18} & $\operatorname{SILP}\left(\mathrm{Me}_{3}-\mathrm{P}-\mathrm{I}\right)$ & aggregates & 78 & 78 & $<1$ & 0 & 0 \\
\hline & $\operatorname{SILP}\left(\mathrm{Bu}_{3}-\mathrm{P}-\mathrm{I}\right)$ & aggregates & $>99$ & 88 & 12 & 0 & 0 \\
\hline & SILP(Oct $\left.{ }_{3}-\mathrm{P}-\mathrm{I}\right)$ & $1.3 \pm 0.3$ & $>99$ & 12 & 87 & $<1$ & $<1$ \\
\hline & $\operatorname{SILP}\left({ }^{\prime} \mathrm{Bu}_{3}-\mathrm{P}-\mathrm{I}\right)$ & $9.9 \pm 4.7$ & 9 & 9 & 0 & 0 & 0 \\
\hline
\end{tabular}

Table 4. Hydrogenation of furfuralacetone using Rh@SILP(Oct $-\mathrm{P}-\mathrm{X})$ with different anions.

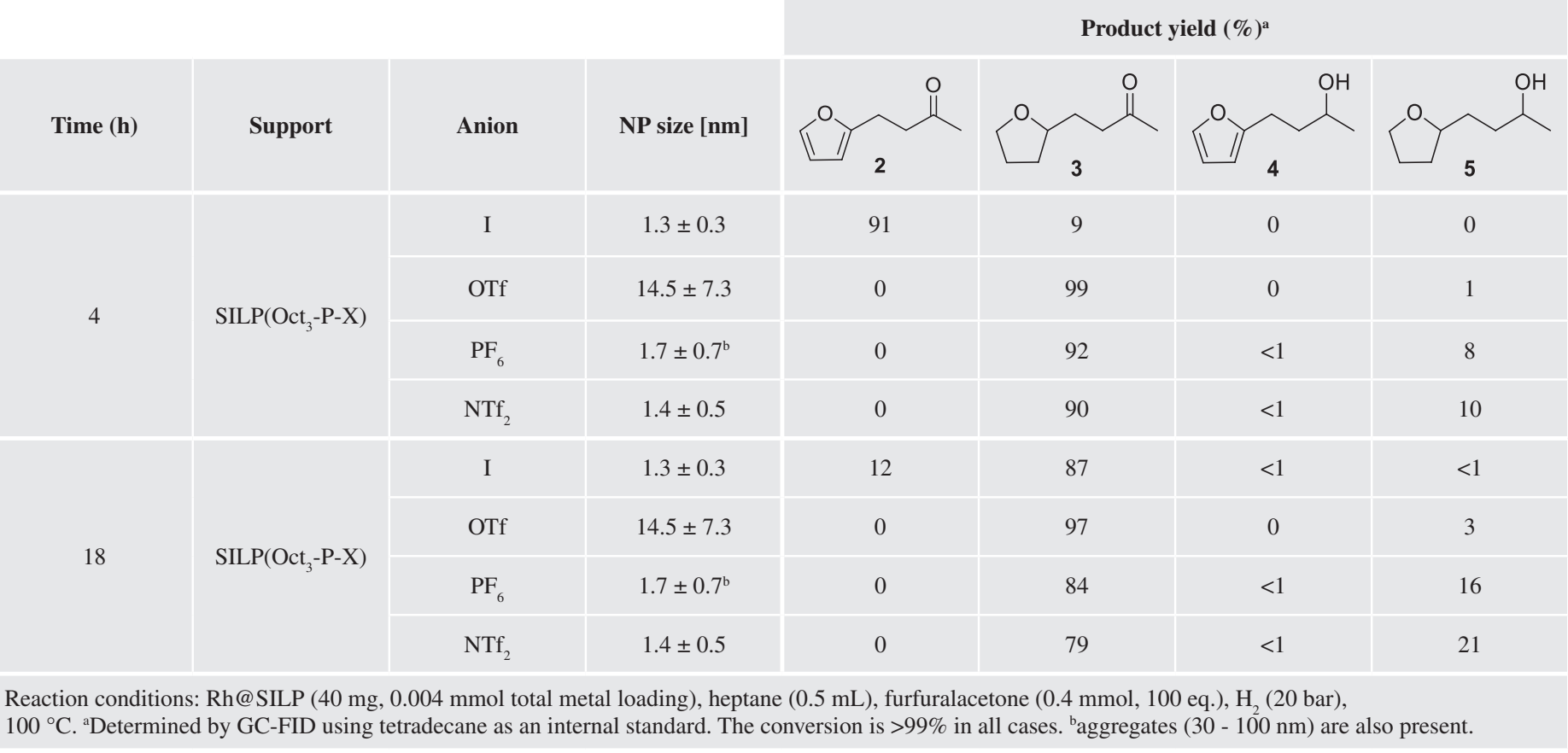

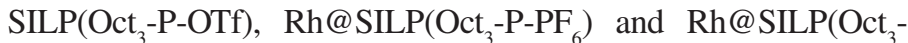
$\mathrm{P}-\mathrm{NTf}_{2}$ ) led to near quantitative yields of $\mathbf{3}$. Ketone hydrogenation activity was observed when using Rh@SILP(Oct $\left.-\mathrm{P}_{3} \mathrm{PF}_{6}\right)$ and $\mathrm{Rh} @ \mathrm{SILP}\left(\mathrm{Oct}_{3}-\mathrm{P}-\mathrm{NTf}_{2}\right)$ as catalysts, with $8 \%$ and $10 \%$ yield of $\mathbf{5}$, respectively.

After 18 h, Rh@SILP(Oct 3 -P-I) and Rh@SILP(Oct $-P-O T f)$ gave 3 as the main product (87\% and $97 \%$ yield, respectively) with only traces of $\mathbf{5}$, indicating that their ketone hydrogenation activity is extremely low. In contrast, significant amounts of $\mathbf{5}$ were detected for reactions catalyzed by Rh@SILP(Oct $\left.-\mathrm{P}-\mathrm{PF}_{6}\right)$ and Rh@SILP(Oct $\left.-\mathrm{P}-\mathrm{NTf}_{2}\right) \quad(16 \%$ and $21 \%$, respectively). Nevertheless, the hydrogenation of the ketone appears to be the slow step for all catalysts tested, and the hydrogenation of $\mathbf{1}$ pro- ceeds clearly through pathway a). Interestingly, the catalytic activity seems to increase with a decrease in coordination strength of the anion $\left(\mathrm{I} \rightarrow \mathrm{OTf} \rightarrow \mathrm{PF}_{6} \rightarrow \mathrm{NTf}_{2}\right)$, which is consistent with what has been described for bulk ILs ${ }^{[19]}$ and SILPs. ${ }^{[20]}$ The absence of $\mathrm{C}=\mathrm{O}$ hydrogenation activity of Rh@SILP(Oct $-\mathrm{P}-\mathrm{OTf})$ may be due to its NPs size. Indeed, we have previously shown that on imidazolium-based SILPs, Rh NPs larger than $2 \mathrm{~nm}$ are essentially inactive for $\mathrm{C}=\mathrm{O}$ hydrogenation. ${ }^{6 \mathrm{6d}]}$ As a result, $\mathrm{Rh} @ \mathrm{SILP}\left(\mathrm{Oct}_{3}-\right.$ P-OTf) proved to be a highly selective catalyst to obtain 3 .

Additionally, the stability of Rh@SILP(Oct $\left.-\mathrm{P}-\mathrm{NTf}_{2}\right)$ was evaluated through recycling experiments (Table 5). The results show that the Rh@SILP(Oct - P-NTf $)$ catalyst maintains its activity for at least 4 cycles. 
Table 5. Recyclability of Rh@SILP(Oct $\left.-\mathrm{P}-\mathrm{NTf}_{2}\right)$ in the hydrogenation of 1 over 4 catalytic cycles (4 h each).

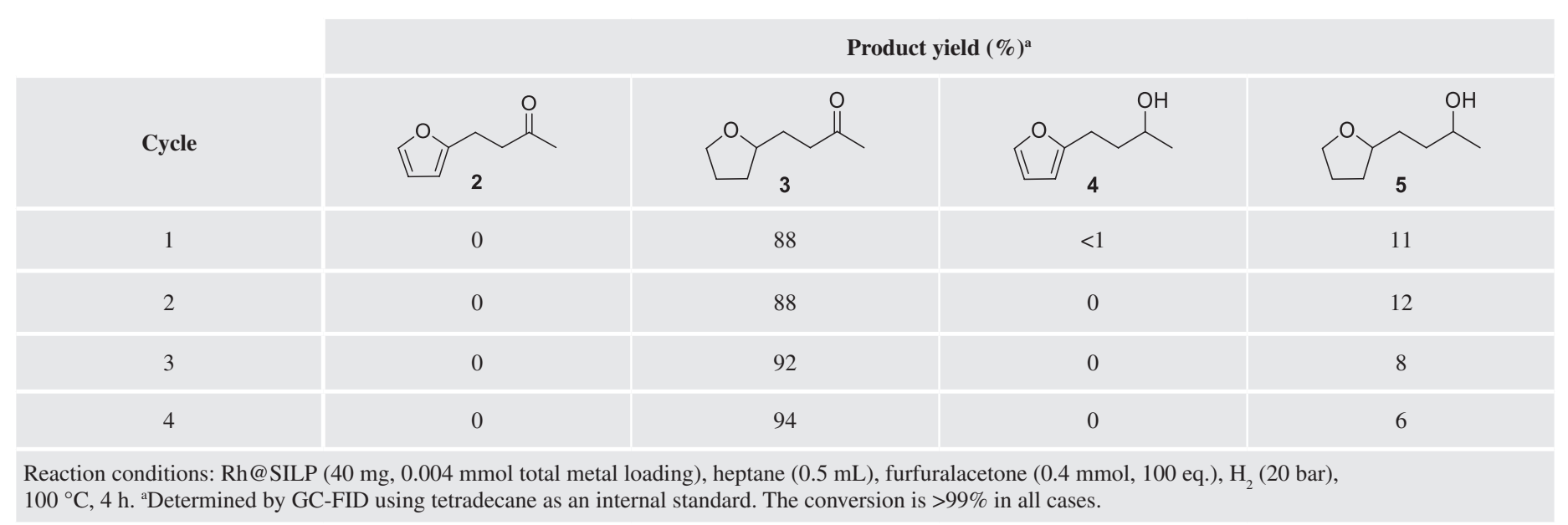

It could be shown that the anion exchange has a large impact on the hydrogenation activity of the Rh@SILP(Oct $-\mathrm{P}-\mathrm{X})$ catalysts, therefore we wanted to investigate the effect of the anion exchange on Rh@SILP $\left({ }^{t} \mathrm{Bu}_{3}-\mathrm{P}-\mathrm{I}\right)$, which had shown the lowest hydrogenation activity of the materials tested thus far in this study. The influence of changing the anion from I to OTf and NTf was $_{2}$ evaluated in the hydrogenation of furfuralacetone over 4 and $18 \mathrm{~h}$ (Table 6).

Despite larger NPs, the hydrogenation activity is superior for $\mathrm{Rh} @ \operatorname{SILP}\left({ }^{t} \mathrm{Bu}\right.$-P-OTf $)$ compared to Rh@SILP $\left({ }^{t} \mathrm{Bu}_{3}-\mathrm{P}-\mathrm{I}\right)$, as evidenced by the larger amount of 2 produced after 4 and $18 \mathrm{~h} \mathrm{(48 \%}$ and $69 \%$ versus $8 \%$ and $9 \%$, respectively). However, no hydrogenation of the furan ring or the ketone could be observed with these catalysts. In sharp contrast, the use of Rh@SILP $\left({ }^{t} \mathrm{Bu}_{3}-\mathrm{P}-\mathrm{NTf}_{2}\right)$ led to full conversion of the substrate after only $4 \mathrm{~h}$, producing a mixture of $\mathbf{3}(69 \%)$ and $\mathbf{5}(28 \%)$. The nature of the anion has thus a crucial influence on the formation and catalytic properties of $\mathrm{Rh}$ NPs prepared on $\operatorname{SILP}\left({ }^{t} \mathrm{Bu}_{3}-\mathrm{P}-\mathrm{X}\right)$. Interestingly, with NPs of similar size $\mathrm{Rh} @ \operatorname{SILP}\left({ }^{t} \mathrm{Bu}_{3}-\mathrm{P}-\mathrm{NTf}_{2}\right)$ clearly outperforms the $\mathrm{C}=\mathrm{O}$ hydrogenation activity of Rh@SILP(Oct $\left.-\mathrm{P}-\mathrm{NTf}_{2}\right)$, even though both catalysts possess well-dispersed NPs of similar size (1.2 and $1.4 \mathrm{~nm}$, respectively). This suggests that other factors than NPs size effect are at play (e.g. electronic and steric interactions, diffusion effects, etc.).

Intriguingly, low mass balances and irreproducible results were obtained when using $\mathrm{Rh} @ \operatorname{SILP}\left({ }^{t} \mathrm{Bu}_{3}-\mathrm{P}-\mathrm{NTf}_{2}\right)$ in $18 \mathrm{~h}$ reactions. Furfuralacetone is known to be a sensitive compound, which is prone to degradation under acidic conditions to form humin. ${ }^{[17 a, b, 21]}$ It could be shown previously that specific phosphonium-based Rh@SILP catalysts can possess acidic properties. ${ }^{[22]}$ For this reason, selected catalysts were also evaluated in the hydrogenation of the less sensitive benzylideneacetone (6, Fig. 5), a model substrate containing similar moieties compared to furfuralacetone.
Very similar to what was presented earlier for furfuralacetone, the first step of the hydrogenation of benzylideneacetone involves the hydrogenation of $\mathrm{C}=\mathrm{C}$ giving 4-phenylbutan-2-one (7). Depending on whether a) the hydrogenation of the aromatic ring or $\mathrm{b}$ ) the $\mathrm{C}=\mathrm{O}$ function is favored, 4-cyclohexylbutan-2-one (8) or 4-phenylbutan-2-ol (9) is yielded next, before both paths merge to give the fully hydrogenated product 4-cyclohexylbutan2-ol (10).

$\mathrm{Rh} @ \operatorname{SILP}\left({ }^{t} \mathrm{Bu}_{3}-\mathrm{P}-\mathrm{NTf}_{2}\right)$, which showed reproducibility issues in the hydrogenation of $\mathbf{1}$, was subsequently tested in the hydrogenation of $\mathbf{6}$ (Table 7) and compared with several other phosphonium-based Rh@SILP catalysts.

Using Rh@SILP $\left({ }^{t} \mathrm{Bu}_{3}-\mathrm{P}-\mathrm{NTf}_{2}\right)$ as catalyst, near full conversion of $\mathbf{6}$ to $\mathbf{1 0}$ was reached after only $1 \mathrm{~h}$ of reaction. Increasing the $\mathrm{Rh}$ :substrate ratio to $500, \mathbf{8}$ was yielded as main product $(77 \%)$, indicating that hydrogenation pathway a) is preferred here as well. For Rh@SILP(Oct $\left.-\mathrm{P}-\mathrm{NTf}_{2}\right)$, the saturated ketone 8 was yielded as main product $(68 \%)$ after $1 \mathrm{~h}$ under standard conditions (100 equivalents of substrate). Rh@SILP( ${ }^{t} \mathrm{Bu}_{3}$-P-OTf) showed a high selectivity towards 7 in $18 \mathrm{~h}$, with negligible $\mathrm{C}=\mathrm{O}$ and aromatic ring hydrogenation activity. Rh@ $\operatorname{SILP}\left({ }^{t} \mathrm{Bu}_{3}-\mathrm{P}-\mathrm{NTf}_{2}\right)$ and $\mathrm{Rh} @ \operatorname{SILP}\left(\mathrm{Oct}_{3}-\mathrm{P}-\mathrm{NTf}_{2}\right)$ were able to fully hydrogenate $\mathbf{6}$ to $\mathbf{1 0}$ in $18 \mathrm{~h}$ reactions. It could be demonstrated that $\mathrm{Rh} @ \operatorname{SILP}\left({ }^{t} \mathrm{Bu}_{3}-\mathrm{P}-\right.$ $\mathrm{NTf}_{2}$ ) can effectively hydrogenate benzylideneacetone. This suggests that the interaction of furfuralacetone with the catalysts and/ or its partial decomposition may have caused the reproducibility issues observed for Rh@SILP $\left({ }^{t} \mathrm{Bu}_{3}-\mathrm{P}-\mathrm{NTf}_{2}\right)$.

\section{Conclusions}

In summary, Rh NPs were immobilized on phosphoniumbased supported ionic liquid phases (Rh@SILP) of systematically varied molecular structure ( $P$-alkyl chain length, anion). The variations of the ionic liquid-type molecular modifier at the silica surface was found to affect the morphology of the synthe-

Fig. 5. Hydrogenation network of benzylideneacetone (6).

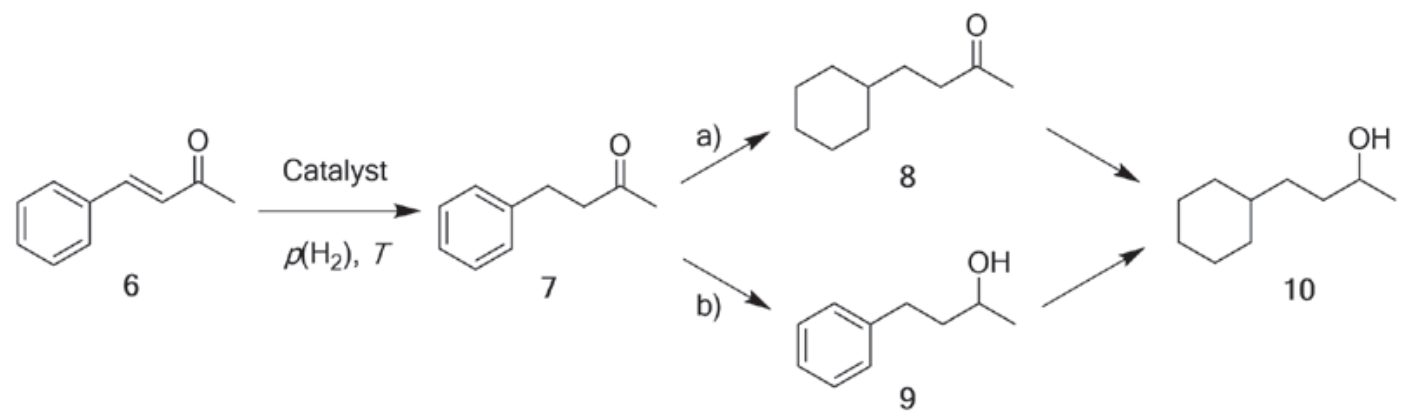


Table 6. Hydrogenation of furfuralacetone using Rh@SILP( $\left(\mathrm{Bu}_{3}-\mathrm{P}-\mathrm{X}\right)$ with different anions.

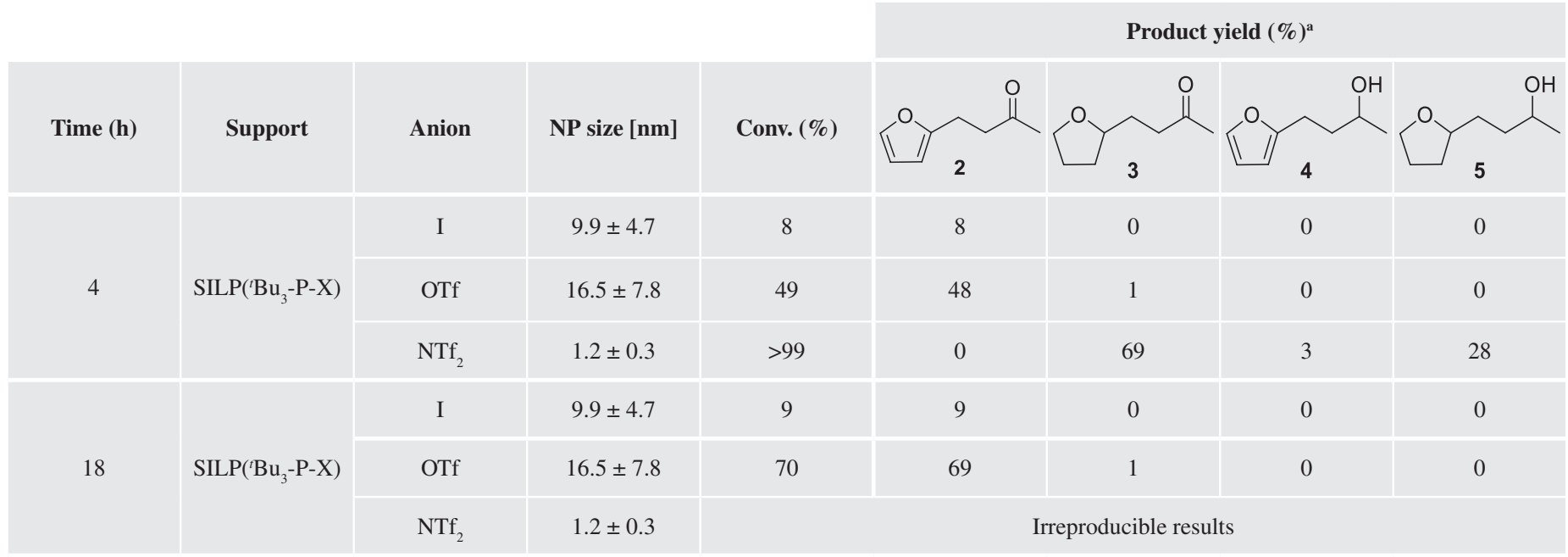

Reaction conditions: Rh@SILP (40.0 mg, 0.004 mmol total metal loading), heptane $(0.5 \mathrm{~mL})$, furfuralacetone $(0.4 \mathrm{mmol}, 100$ eq. $)$, $\mathrm{H}_{2}$ ( $\left.20 \mathrm{bar}\right)$,

$100{ }^{\circ} \mathrm{C}$. ${ }^{a}$ Determined by GC-FID using tetradecane as an internal standard.

Table 7. Hydrogenation of benzylideneacetone using different phosphonium-based Rh@SILP catalysts.

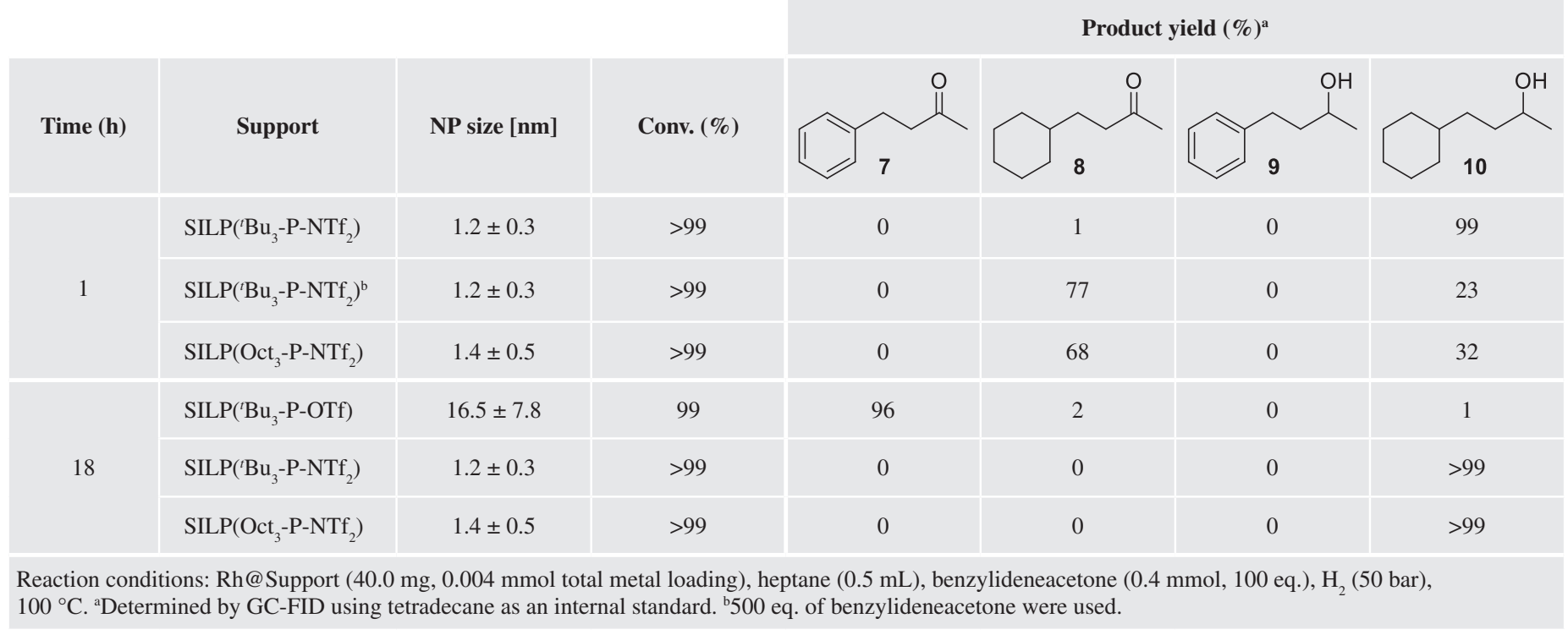

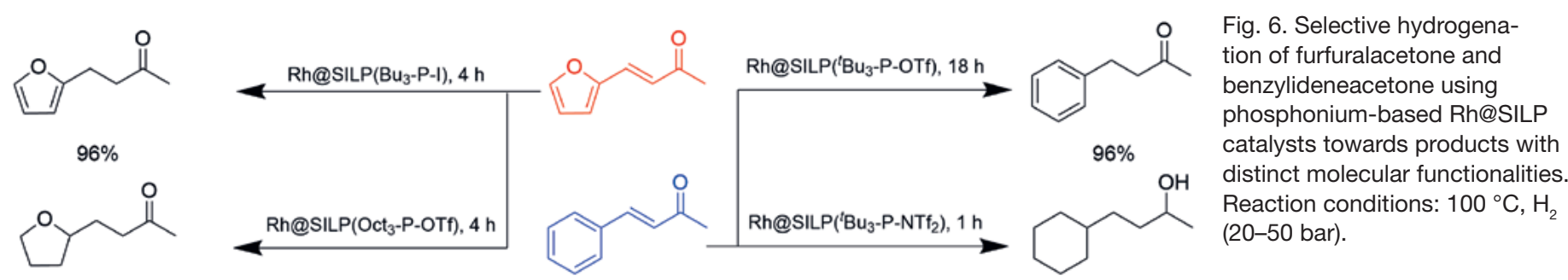

$99 \%$

$99 \%$

sized nanoparticles in a much stronger manner than what has been previously observed on imidazolium-based SILPs. The catalytic properties of Rh@SILP materials in hydrogenation were investigated using biomass-derived furfuralacetone as well as benzylideneacetone as molecular probes. All the catalysts considered displayed some activity for the hydrogenation of these substrates, however with very significant differences depending on the NPs size and molecular structure of the SILP, leading to the selec- tive synthesis of products with distinct molecular functionalities (Fig. 6). In particular, catalysts containing I as anion were found poorly active and did not hydrogenate the $\mathrm{C}=\mathrm{O}$ at all, presumably due to the presence of large NPs and the poisoning of the NPs surface by the I. Decreasing the coordination strength of the anion from I, to OTf, $\mathrm{PF}_{6}$ and $\mathrm{NTf}_{2}$ led to a progressive increase in catalytic activity and unlocked ${ }^{2} \mathrm{C}=\mathrm{O}$ hydrogenation activity. Similarly, increasing the length of the P-alkyl chain was ben- 
eficial for the formation of small and well-dispersed NPs with high catalytic activity. Additionally, several Rh@SILP materials showed high activity for the hydrogenation of benzylideneacetone, fully hydrogenating the substrate in short reaction times. While the effects observed in catalysis may be caused by several factors (NPs size effect, electronic interaction, diffusion, etc.) that are currently challenging to untangle, the trends resulting from the variation of the anion and $P$-alkyl chains can be used as basis for future studies involving metal NPs immobilized on phosphonium-based SILP as catalysts.

\section{Acknowledgements}

The authors acknowledge financial support by the Max Planck Society and by the Deutsche Forschungsgemeinschaft (DFG, German Research Foundation) under Germany's Excellence StrategyExzellenzcluster 2186 'The Fuel Science Center' ID: 390919832. We thank Karl-Josef Vaeßen (ITMC, RWTH Aachen University) and Natalia Kowalew (Max-Planck-Institut für Chemische Energiekonversion, Mülheim an der Ruhr) for $\mathrm{N}_{2}$ (g) adsorption measurements and Bernd Spliethoff, Lucas Schulte-Zweckel and Adrian Schlüter (Max-PlanckInstitut für Kohlenforschung, Mülheim an der Ruhr) for TEM analysis.

\section{Supplementary Information}

Supplementary information is available on https://www.ingentaconnect.com/content/scs/chimia.

Received: May 6, 2021

[1] a) A. Corma, S. Iborra, A. Velty, Chem. Rev. 2007, 107, 2411, https://doi.org/10.1021/cr050989d; b) W. P. Nel, C. J. Cooper, Energy Policy 2009, 37, 166, https://doi.org/10.1016/j.enpol.2008.08.013; c) D. M. Alonso, J. Q. Bond, J. A. Dumesic, Green. Chem. 2010, 12, 1493 , https://doi.org/10.1039/C004654J; d) M. A. Rubio Rodríguez, J. D. Ruyck, P. R. Díaz, V. K. Verma, S. Bram, App. Energy 2011, 88, 630, https://doi.org/10.1016/j.apenergy.2010.08.013; e) M. J. Climent, A. Corma, S. Iborra, Green. Chem. 2014, 16, 516, https://doi.org/10.1039/C3GC41492B; f) M. Besson, P. Gallezot, C. Pinel, Chem. Rev. 2014, 114, 1827, https://doi.org/10.1021/ cr4002269; g) W. Leitner, J. Klankermayer, S. Pischinger, H. Pitsch, K. Kohse-Höinghaus, Angew. Chem. Int. Ed. 2017, 56, 5412, https://doi.org/10.1002/anie.201607257; h) A. Herbst, C. Janiak, CrystEngComm 2017, 19, 4092, https://doi.org/10.1039/C6CE01782G.

[2] a) T. Werpy, G. Petersen, 'Top Value Added Chemicals from Biomass: Volume I -- Results of Screening for Potential Candidates from Sugars and Synthesis Gas', National Renewable Energy Lab., Golden, CO (US), 2004; b) J. R. Rostrup-Nielsen, Science 2005, 308, 1421, https://doi.org/10.1126/science.1113354; c) R. A. Sheldon, Catal. Today 2011， 167, 3, https://doi.org/10.1016/j.cattod.2010.10.100; d) M. J. Climent, A. Corma, S. Iborra, Green. Chem. 2011, 13, 520, https://doi.org/10.1039/C0GC00639D; e) R. S. Dhillon, G. von Wuehlisch, Biomass Bioenergy 2013, 48, 75, https://doi.org/10.1016/j.biombioe.2012.11.005; f) R. A. Sheldon, Green. Chem. 2014, 16, 950, https://doi.org/10.1039/C3GC41935E.

[3] a) G. Brieger, T. J. Nestrick, Chem. Rev. 1974, 74, 567, https://doi.org/10.1021/cr60291a003; b) R. A. W. Johnstone, A. H. Wilby, I. D. Entwistle, Chem. Rev. 1985, 85, 129, https://doi.org/10.1021/cr00066a003; c) H.-U. Blaser, C. Malan, B. Pugin, F. Spindler, H. Steiner, M. Studer, Adv. Synth. Catal. 2003, 345, 103, https://doi.org/10.1002/adsc.200390000; d) J. G. de Vries, C. J. Elsevier, 'The Handbook of Homogeneous Hydrogenation', WileyVCH, Weinheim, 2007; e) P. G. Andersson, I. J. Munslow, 'Modern Reduction Methods', Wiley-VCH, Weinheim, 2008; f) D. Wang, D. Astruc, Chem. Rev. 2015, 115, 6621, https://doi.org/10.1021/acs. chemrev.5b00203; g) F. Meemken, A. Baiker, Chem. Rev. 2017, 117, 11522, https://doi.org/10.1021/acs.chemrev.7b00272; h) L. Alig, M. Fritz, S. Schneider, Chem. Rev. 2019, 119, 2681, https://doi.org/10.1021/acs.chemrev.8b00555.

[4] a) J. M. Notestein, A. Katz, Chem. Eur. J. 2006, 12, 3954, https://doi.org/10.1002/chem.200501152; b) U. Díaz, D. Brunel, A. Corma, Chem. Soc. Rev. 2013, 42, 4083, https://doi.org/10.1039/C2CS35385G; c) M. Haumann, P. Wasserscheid, 'SILP and SCILL catalysis', Royal Society of Chemistry, 2014; d) B. Xin, J. Hao, Chem. Soc. Rev. 2014, 43, 7171, https://doi.org/10.1039/C4CS00172A; e) R. Ye, J. Zhao, B. B. Wickemeyer, F. D. Toste, G. A. Somorjai, Nat. Catal. 2018, 1, 318, https://doi.org/10.1038/s41929-018-0052-2; f) A. Bordet, W. Leitner, Acc. Chem. Res. 2021, https://doi.org/10.1021/acs.accounts.1c00013.

[5] a) L. Luza, A. Gual, C. P. Rambor, D. Eberhardt, S. R. Teixeira, F. Bernardi, D. L. Baptista, J. Dupont, Phys. Chem. Chem. Phys. 2014, 16, 18088, https://doi.org/10.1039/C4CP03063J; b) K. L. Luska, A. Bordet, S. Tricard, I. Sinev, W. Grünert, B. Chaudret, W. Leitner, ACS Catal. 2016, 6, 3719, https://doi.org/10.1021/acscatal.6b00796; c) F. P. da Silva, J. L. Fiorio, L. M. Rossi, ACS Omega 2017, 2, 6014, https://doi.org/10.1021/acsomega.7b00836; d) L. Luza, A. Gual, J. A. Fernandes, D. Eberhardt, J. Dupont, Phys. Chem. Chem. Phys. 2019, 21 , 16615, https://doi.org/10.1039/C9CP03012C; e) S. El Sayed, A. Bordet, C. Weidenthaler, W. Hetaba, K. L. Luska, W. Leitner, ACS Catal. 2020 10, 2124, https://doi.org/10.1021/acscatal.9b05124; f) S. Kacem, M. Emondts, A. Bordet, W. Leitner, Catal. Sci. Technol. 2020, 10, 8120 https://doi.org/10.1039/D0CY01716G; g) S. Rengshausen, C. Van Stappen, N. Levin, S. Tricard, K. L. Luska, S. DeBeer, B. Chaudret, A. Bordet, W. Leitner, Small 2021, 17, 2006683, https://doi.org/10.1002/ smll.202006683.

[6] a) T. Jiang, Y. Zhou, S. Liang, H. Liu, B. Han, Green. Chem. 2009, 11 , 1000, https://doi.org/10.1039/B901425J; b) H. Li, P. S. Bhadury, B. Song, S. Yang, RSC Adv. 2012, 2, 12525, https://doi.org/10.1039/C2RA21310A; c) P. Migowski, K. L. Luska, W. Leitner, in 'Nanocatalysis in Ionic Liquids', Ed.: M. H. G. Prechtl, Wiley-VCH, Weinheim, 2016, pp. 249; d) A. Bordet, G. Moos, C. Welsh, P. Licence, K. L. Luska, W. Leitner, ACS Catal. 2020, 10, 13904, https://doi.org/10.1021/acscatal.0c03559.

[7] a) K. L. Luska, J. Julis, E. Stavitski, D. N. Zakharov, A. Adams, W. Leitner, Chem. Sci. 2014, 5, 4895, https://doi.org/10.1039/C4SC02033B b) K. L. Luska, P. Migowski, S. El Sayed, W. Leitner, Angew. Chem. Int. Ed. 2015, 54, 15750, https://doi.org/10.1002/anie.201508513; c) L. Offner-Marko, A. Bordet, G. Moos, S. Tricard, S. Rengshausen, B. Chaudret, K. L. Luska, W. Leitner, Angew. Chem. Int. Ed. 2018, 57, 12721 , https://doi.org/10.1002/anie.201806638; d) S. Rengshausen, F. Etscheidt, J. Großkurth, K. L. Luska, A. Bordet, W. Leitner, Synlett 2019, 30, 405, https://doi.org/10.1055/s-0037-1611678; e) L. Goclik, L. OffnerMarko, A. Bordet, W. Leitner, Chem. Commun. 2020, 56, 9509, https://doi.org/10.1039/D0CC03695A.

[8] L. Luza, C. P. Rambor, A. Gual, F. Bernardi, J. B. Domingos, T. Grehl, P. Brüner, J. Dupont, ACS Catal. 2016, 6, 6478, https://doi.org/10.1021/acscatal.6b01813.

[9] a) M.-C. Tseng, H.-C. Kan, Y.-H. Chu, Tetrahedron Lett. 2007 , 48, 9085, https://doi.org/10.1016/j.tetlet.2007.10.131; b) K J. Fraser, D. R. MacFarlane, Aust. J. Chem. 2009, 62, 309, https://doi.org/10.1071/CH08558; c) S. Sowmiah, V. Srinivasadesikan, M.-C. Tseng, Y.-H. Chu, Molecules 2009, 14, 3780 , https://doi.org/10.3390/molecules14093780; d) D. R. MacFarlane, M. Forsyth, E. I. Izgorodina, A. P. Abbott, G. Annat, K. Fraser, Phys. Chem. Chem. Phys. 2009, 11, 4962, https://doi.org/10.1039/B900201D; e) L. Ford, F. Atefi, R. D. Singer, P. J. Scammells, Eur. J. Org. Chem. 2011, 2011, 942, https://doi.org/10.1002/ejoc.201001468.

[10] a) D. Arkhipova, V. Ermolaev, V. Miluykov, G. Gaynanova, L. Zakharova, G. Wagner, O. Oeckler, E. Hey-Hawkins, J. Organomet. Chem. 2020, 923, 121454, https://doi.org/10.1016/j.jorganchem.2020.121454; b) H. A. Kalviri, F. M. Kerton, Green. Chem. 2011, 13, 681, https://doi.org/10.1039/C0GC00851F; c) D. M. Arkhipova, V V. Ermolaev, V. A. Miluykov, A. T. Gubaidullin, D. R. Islamov, O. N. Kataeva, V. P. Ananikov, Nanomaterials 2020, 10, 2457, https://doi.org/10.3390/nano10122457.

[11] a) A. Banerjee, R. Theron, R. W. J. Scott, ChemSusChem 2012, 5, 109 , https://doi.org/10.1002/cssc.201100413; b) A. Banerjee, R. W. J. Scott, Green. Chem. 2015, 17, 1597, https://doi.org/10.1039/C4GC01716A.

[12] K. L. Luska, A. Moores, Green. Chem. 2012, 14, 1736 , https://doi.org/10.1039/C2GC35241A.

[13] a) C. Moreau, R. Durand, D. Peyron, J. Duhamet, P. Rivalier, Ind. Crop Prod. 1998, 7, 95, https://doi.org/10.1016/S0926-6690(97)00037-X; b) J. N. Chheda, G. W. Huber, J. A. Dumesic, Angew. Chem. Int. Ed. 2007, 46, 7164, https://doi.org/10.1002/anie.200604274; c) G. W. Huber, S. Iborra, A. Corma, Chem. Rev. 2006, 106, 4044, https://doi.org/10.1021/cr068360d; d) H. Wang, J. Male, Y. Wang, ACS Catal. 2013, 3, 1047, https://doi.org/10.1021/cs400069z.

[14] a) G. W. Huber, J. N. Chheda, C. J. Barrett, J. A. Dumesic, Science 2005 308, 1446, https://doi.org/10.1126/science.1111166; b) C. J. Barrett, J. N. Chheda, G. W. Huber, J. A. Dumesic, Appl. Catal. B 2006, 66, 111, https://doi.org/10.1016/j.apcatb.2006.03.001.

[15] C. J. Bradaric, A. Downard, C. Kennedy, A. J. Robertson, Y. Zhou, Green. Chem. 2003, 5, 143, https://doi.org/10.1039/B209734F.

[16] S. Ahrens, A. Peritz, T. Strassner, Angew. Chem. Int. Ed. 2009, 48, 7908, https://doi.org/10.1002/anie.200903399.

[17] a) W. Xu, Q. Xia, Y. Zhang, Y. Guo, Y. Wang, G. Lu, ChemSusChem 2011, 4, 1758, https://doi.org/10.1002/cssc.201100361; b) R. Ramos, Z. Tišler, O. Kikhtyanin, D. Kubička, Catal. Sci. Technol. 2016, 6, 1829, https://doi.org/10.1039/C5CY01422K; c) M. Strohmann, 
A. Bordet, A. J. Vorholt, W. Leitner, Green. Chem. 2019, 21, 6299, https://doi.org/10.1039/C9GC02555C.

[18] M. D. Argyle, C. H. Bartholomew, Catalysts 2015, 5, 145, https://doi.org/10.3390/catal5010145.

[19] C. W. Scheeren, G. Machado, S. R. Teixeira, J. Morais, J. B. Domingos, J. Dupont, J. Phys. Chem. B 2006, 110, 13011, https://doi.org/10.1021/jp0623037.

[20] M. Ruta, G. Laurenczy, P. J. Dyson, L. Kiwi-Minsker, J. Phys. Chem. C 2008, 112, 17814, https://doi.org/10.1021/jp806603f.

[21] a) J. Julis, W. Leitner, Angew. Chem. Int. Ed. 2012, 51, 8615, https://doi.org/10.1002/anie.201203669; b) H. Olcay, A. V. Subrahmanyam, R. Xing, J. Lajoie, J. A. Dumesic, G. W. Huber, Energy Environ. Sci. 2013, 6, 205, https://doi.org/10.1039/C2EE23316A; c) R. Ramos, Z. Tišler, O. Kikhtyanin, D. Kubička, Appl. Catal. A Gen. 2017, 530, 174, https://doi.org/10.1016/j.apcata.2016.11.023.

[22] G. Moos, M. Emondts, A. Bordet, W. Leitner, Angew. Chem. Int. Ed. 2020, 59, 11977, https://doi.org/10.1002/anie.201916385.

License and Terms

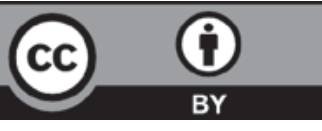

This is an Open Access article under the terms of the Creative Commons Attribution License CC BY 4.0. The material may not be used for commercial purposes.

The license is subject to the CHIMIA terms and conditions: (http:// chimia.ch/component/sppagebuilder/?view=page \&id=12).

The definitive version of this article is the electronic one that can be found at https://doi.org/10.2533/chimia.2021.724 